\title{
Insecticidal Activity of Some Traditionally Used Ethiopian Medicinal Plants against Sheep Ked Melophagus ovinus
}

\author{
Negero Gemeda, ${ }^{1}$ Walelegn Mokonnen, ${ }^{1}$ Hirut Lemma, ${ }^{1}$ Ashenif Tadele, ${ }^{1}$ \\ Kelbessa Urga, ${ }^{1}$ Getachew Addis, ${ }^{1}$ Asfaw Debella, ${ }^{1}$ Mesaye Getachew, ${ }^{1}$ Frehiwot Teka, ${ }^{1}$ \\ Kidist Yirsaw, ${ }^{1}$ Kissi Mudie, ${ }^{1}$ and Solomon Gebre ${ }^{2}$ \\ ${ }^{1}$ Traditional and Modern Medicine Research Directorate, Ethiopian Health and Nutrition Research Institute, \\ P.O. Box 1242, Addis Ababa, Ethiopia \\ ${ }^{2}$ National Animal Health Diagnostic and Investigation Center, P.O. Box 04, Sebeta, Ethiopia \\ Correspondence should be addressed to Negero Gemeda; 4negero@gmail.com
}

Received 12 August 2013; Revised 22 November 2013; Accepted 10 December 2013; Published 4 February 2014

Academic Editor: Wej Choochote

Copyright (C) 2014 Negero Gemeda et al. This is an open access article distributed under the Creative Commons Attribution License, which permits unrestricted use, distribution, and reproduction in any medium, provided the original work is properly cited.

\begin{abstract}
Twelve medicinal plants and a commercially used drug Ivermectin were examined for insecticidal activity against Melophagus ovinus sheep ked at different time intervals using in vitro adult immersion test. The findings show that at $3.13 \mu \mathrm{L} / \mathrm{mL}, 6.25 \mu \mathrm{L} / \mathrm{mL}$ and $12.5 \mu \mathrm{L} / \mathrm{mL}$ concentration of Cymbopogon citratus, Foeniculum vulgare and Eucalyptus globulus essential oils respectively, recorded $100 \%$ mortalities against $M$. ovinus within 3 hour of exposure. Significantly higher insecticidal activity of essential oils was recorded $(P=0.00)$ when compared to $10 \mu \mathrm{g} / \mathrm{mL}$ Ivermectin after 3-hour exposure of $M$. ovinus at a concentration of $\geq 1.57 \mu \mathrm{L} / \mathrm{mL}, \geq 3 \mu \mathrm{L} / \mathrm{mL}$, and $\geq 12.7 \mu \mathrm{L} / \mathrm{mL}$ essential oils of C. citratus, F. vulgare, and E. globulus, respectively. Among essential oils, C. citratus has showed superior potency at a three-hour exposure of the parasite $(P=0.00)$ at a concentration of $\geq 0.78 \mu \mathrm{L} / \mathrm{mL}$. Strong antiparasitic activity was recorded by aqueous extract of Calpurnia aurea ( $80 \%$ mortality) at a concentration of $200 \mathrm{mg} / \mathrm{mL}$ within $24 \mathrm{~h}$ among aqueous extracts of 9 medicinal plants. The results indicated all the four medicinal plants, particularly those tested essential oils, can be considered as potential candidates for biocontrol of M. ovinus sheep ked.
\end{abstract}

\section{Introduction}

In Ethiopia, a livestock sector contribute for $12 \%$ of the total Gross Domestic Product (GDP), and provides livelihood for $65 \%$ of the population and also it accounts for $37-87 \%$ out of the total house hold cash income. For many years not only the export of livestock but also the export of processed and semiprocessed skins and hide constitutes Ethiopia's second largest export commodity by accounting for $12-15 \%$ of the total export earnings next to coffee $[1,2]$. This has been deteriorating with an increasing number of reject grades and appearance of a skin disease called "Ekek" that is mainly due to ectoparasites infestation $[3,4]$. Thirty years ago, tanneries in Ethiopia used to produce $70 \%$ of processed skins with grades $1-3$. About $10-20 \%$ of the skins were graded as being of poor quality. Currently, only $10-15 \%$ is in the good category while the rest are downgraded or rejected due to increasing external parasite infestations [5]. Ectoparasite infections have been responsible for major economic loss in leather industry in Ethiopia in which approximately more than half of the skin reject occurs $[3,4,6]$.

Among ectoparasites, Melophagus ovinus sheep keds are the most economically important pests of sheep [4, 7-9]. Melophagus ovinus sheep ked is a voracious blood sucker causing great irritation to the sheep and forcing them to scratch and bite at themselves [10]. The parasites are reported to cause discomfort and annoyance that leads to reduction of weight gain, wool growth, and milk production due to nervousness and improper nutrition of the animals in which they spend less time feeding. Moreover, sheep ked is reported to cause inflammation, and as the host attempts to alleviate this irritation, wool loss and skin damage can be caused. 
Other report, showed that heavily infested animals become weak and unthrifty and show weight loss, anemia, wool staining, reduced resistance to disease, and a condition called "cockle" which is a series of pimple-like bumps on the skin of the sheep in areas where keds have fed [3,7]. They reduce the value of the skin. If skins are used in the tanning industry, the bumps will not accept dye like the rest of the pelt and the pelt no longer demands high prices.

In addition, $M$. ovinus sheep ked reduces the growth rates and also causes paralysis and injuries which lead to secondary infection and expose the animal to cutaneous myiasis [11]. Further economic losses result from the effects of feeding and scratching on the skin with hard nodules (cockle) reducing the value of the hide. Wool loss from scratching and biting and the staining of the fleece caused by ked feces in the fleece are further economic effects [10]. Sheep ked also creates financial burdens of diagnostic, therapeutic or preventive programs at flock, community and national levels.

As a result control strategies are looked for to reduce disease and limit losses in the animal husbandry industry to or below acceptable economic damage thresholds $[12,13]$. Highly potent chemical insecticides such as organophosphate compounds are routinely and extensively used interventions in ectoparasite control of livestock [5]. However, widespread intensive use of synthetic insecticide has led to pesticide resistance in parasite populations $[7,14,15]$. Besides, their continuous application was coupled with environmental pollution and health concerns by causing the contamination of ground water by particle leachates and toxicity of the chemicals on animals and increasing incidence of human skin, lung, nerve disease upon exposure to these chemicals [7].

Most of the pesticides that are currently used against the various animal ectoparasites in Ethiopia are organophosphorus compounds which cause both contact and stomach poison [16]. They are acting by combining with, and neutralizing cholinesterase action, an enzyme responsible for the hydrolysis of acetylcholine which is synthesized at nerve endings and is involved in the transmission of impulses from nerve to nerve or effecter cells $[16,17]$. Previous investigations in Ethiopia have clearly indicated depression of cholinesterase activity associated with symptoms of intoxication among agricultural workers due to lower plasma cholinesterase and erythrocyte cholinesterase of the workers $[18,19]$.

As the traditional approach to control M. ovinus infestations has been only partially successful due to the costs of insecticides, resistance, and environmental contamination, alternative anti-sheep ked products and or control strategies that are safe, cost-effective, and environmentally friendly are therefore necessary [20]. Ethnoveterinary medicine (EVM) specially the use of medicinal plants could be a promising area of alternative sheep ked control strategies. The value of medicinal plants as commercial sheep ked control agents has yet to be proven, but their high safety and effectiveness make them promising candidates for use as commercial sheep ked biocontrol agents [21].
In Ethiopia, there are a number of medicinal plants utilized by EVM practitioners to control ectoparasites infection in livestock. Among them Aloe sp. (Family Asparagaceae), Bersama abyssinica Fresen. (Melianthaceae), Calpurnia aurea (Aition) Benth. (Fabaceae), Croton macrostachyus Hochst. ex Delile. (Euphorbiaceae), Cymbopogon citratus (DC.) Stapf (Poaceae), Eucalyptus globulus Labill. (Myrtaceae), Foeniculum vulgare Mill. (Apiaceae), Jatropha curcas L. (Euphorbiaceae), Nicotiana tabacum L. (Solanaceae), Syzygium guineense (Willd.) DC. (Myrtaceae), Vernonia auriculifera Hiern. (Asteraceae), and Ximenia caffra Sond. (Olacaceae) were mainly used in EVM [22-28]. The study was therefore conducted to evaluate the in vitro bioinsecticidal efficacy of indigenous plants used in EVM practice in Ethiopia for the control of M. ovinus sheep ked.

\section{Material and Methods}

2.1. Experimental Parasite Collection and Maintenance. Melophagus ovinus sheep ked parasite was used in this study to conduct in vitro insecticidal assay of medicinal plants. Sheep keds were collected from naturally infested sheep around Fiche, North Shewa, Oromia Zone, Ethiopia. The identity of the parasites was confirmed on site by veterinary professionals found in the collection area. After their identification, the parasites were maintained in plastic cups into which water soaked cottons were placed to increase the humidity of the air found in the cups. The cups were covered by gauze to allow the free circulation of air into the cups. And the parasites were transported to the Fiche Animal Health Clinic Laboratory where the experimental works were conducted.

\subsection{Plant Material Collection, Identification, and Extraction.} Eucalyptus globulus and Cymbopogon citratus essential oils were obtained from Wondo Genet Agricultural Research Center, Ethiopia. Essential oils of Foeniculum vulgare Mill. were extracted by hydrodistillation of the fresh leaf which was collected from Shashamane, Ethiopia. Fresh plant materials $(250 \mathrm{~g})$ were placed in a $5 \mathrm{~L}$ round-bottom distillation flask and the plant material was wetted with $3 \mathrm{~L}$ distilled water. The essential oils were obtained by hydrodistillation using Clevenger-type apparatus for continuous $3 \mathrm{~h}$. The volatile oil was taken from the upper layer. The excess aqueous layers were further portioned using dichloromethane extract and enrich the essential oil from the water layer. The organic layer (dichloromethane extract) was filtered and dried with anhydrous sodium sulfate and concentrated using rotary evaporator to give the crude essential oil.

Three hundred grams of dry powdered leaves of Calpurnia aurea (leaves), Syzygium guineense (leaves), Bersama abyssinica (leaves), Croton macrostachyus (leaves), Nicotiana tabacum (leaves), Vernonia auriculifera (leaves), Aloe species (aerial part), and the fruits of Jatropha curcas and Ximenia caffra was macerated with $25-50 \mathrm{~mL}$ water. The aqueous extracts were filtered using gauze and freeze dried using lyophilizer. The volatile oils and the amorphous residues from the aqueous macerate are kept in the refrigerator and 
TABlE 1: The corrected mortalities of M. ovinus sheep keds exposed to different concentrations of C. citratus, F. vulgare, and E. globulus essential oils from the leaves.

\begin{tabular}{|c|c|c|c|c|c|c|}
\hline \multirow{3}{*}{ Dose $(\mathrm{mg} / \mathrm{mL})$} & \multicolumn{6}{|c|}{ Corrected mortality rate (\%) } \\
\hline & \multicolumn{2}{|c|}{ E. globulus } & \multicolumn{2}{|c|}{ C. citratus } & \multicolumn{2}{|c|}{ F. vulgare } \\
\hline & $3 \mathrm{~h}$ PI & 24 h PI & $3 \mathrm{~h}$ PI & $24 \mathrm{~h}$ PI & $3 \mathrm{~h}$ PI & $24 \mathrm{~h}$ PI \\
\hline 0.7825 & $0.00 \pm 0.0^{\mathrm{d}}$ & $0.00 \pm 0.0^{c}$ & $16.7 \pm 0.6^{c}$ & $43.3 \pm 1.15^{\mathrm{b}}$ & $0.00 \pm 0.0^{\mathrm{e}}$ & $0.00 \pm 0.0^{\mathrm{d}}$ \\
\hline 1.565 & $0.00 \pm 0.0^{\mathrm{d}}$ & $6.70 \pm 0.6^{\mathrm{c}}$ & $93.3 \pm 0.6^{\mathrm{a}}$ & $93.3 \pm 0.6^{\mathrm{a}}$ & $53.3 \pm 0.6^{\mathrm{d}}$ & $53.3 \pm 1.2^{\mathrm{c}}$ \\
\hline 3.13 & $56.7 \pm 0.6^{c}$ & $66.7 \pm 1.2^{\mathrm{b}}$ & $100.0 \pm 0.0^{\mathrm{a}}$ & $100.0 \pm 0.0^{\mathrm{a}}$ & $86.7 \pm 0.6^{\mathrm{b}}$ & $86.7 \pm 0.6^{b}$ \\
\hline 6.25 & $83.3 \pm 1.0^{\mathrm{b}}$ & $86.7 \pm 0.6^{\mathrm{a}}$ & $100.0 \pm 0.0^{\mathrm{a}}$ & $100.0 \pm 0.0^{\mathrm{a}}$ & $100.0 \pm 0.0^{\mathrm{a}}$ & $100.0 \pm 0.0^{\mathrm{a}}$ \\
\hline 12.5 & $100.0 \pm 0.0^{\mathrm{a}}$ & $100.0 \pm 0.0^{\mathrm{a}}$ & $100.0 \pm 0.0^{\mathrm{a}}$ & $100.0 \pm 0.0^{\mathrm{a}}$ & $100.0 \pm 0.0^{\mathrm{a}}$ & $100.0 \pm 0.0^{\mathrm{a}}$ \\
\hline 25 & $100.0 \pm 0.0^{\mathrm{a}}$ & $100.0 \pm 0.0^{\mathrm{a}}$ & $100.0 \pm 0.0^{\mathrm{a}}$ & $100.0 \pm 0.0^{\mathrm{a}}$ & $100.0 \pm 0.0^{\mathrm{a}}$ & $100.0 \pm 0.0^{\mathrm{a}}$ \\
\hline 50 & $100.0 \pm 0.0^{\mathrm{a}}$ & $100.0 \pm 0.0^{\mathrm{a}}$ & $100.0 \pm 0.0^{\mathrm{a}}$ & $100.0 \pm 0.0^{\mathrm{a}}$ & $100.0 \pm 0.0^{\mathrm{a}}$ & $100.0 \pm 0.0^{\mathrm{a}}$ \\
\hline Control $^{+}$ & $73.3 \pm 0.6^{\mathrm{b}}$ & $100.0 \pm 0.0^{\mathrm{a}}$ & $73.3 \pm 0.6^{\mathrm{b}}$ & $100.0 \pm 0.0^{\mathrm{a}}$ & $73.3 \pm 0.6^{c}$ & $100.0 \pm 0.0^{\mathrm{a}}$ \\
\hline
\end{tabular}

${ }^{+}$Ivermectin $(10 \mu \mathrm{g} / \mathrm{mL})$; PI: postincubation; values are expressed as mean \pm SD. Mean values with different letters in the same column are significantly different $(P<0.05)$.

desiccators, respectively, until used for the in vitro insecticidal susceptibility assay.

\subsection{Insecticidal Assay}

2.3.1. Adult Immersion Test. Insecticidal activity of 12 plant extracts was performed using adult immersion test according to Drummond et al. (1976) as cited in [29]. Twofold serial dilutions of plants essential oils $(50 \mu \mathrm{L} / \mathrm{mL}, 25 \mu \mathrm{L} / \mathrm{mL}$, $12.5 \mu \mathrm{L} / \mathrm{mL}, \quad 6.25 \mu \mathrm{L} / \mathrm{mL}, 3.125 \mu \mathrm{L} / \mathrm{mL}, 1.5625 \mu \mathrm{L} / \mathrm{mL}$, and $0.78125 \mu \mathrm{L} / \mathrm{mL}$ ) were prepared in $2 \%$ aqueous solution of Tween 80 . Similarly, twofold serial dilutions of aqueous plants extracts $(200 \mathrm{mg} / \mathrm{mL}, 100 \mathrm{mg} / \mathrm{mL}, 50 \mathrm{mg} / \mathrm{mL}, 25 \mathrm{mg} / \mathrm{mL}$, $12.5 \mathrm{mg} / \mathrm{mL}$, and $6.25 \mathrm{mg} / \mathrm{mL}$ ) were prepared in distilled water. Antiparasitic effects of each dilution were tested by immersing a group of $10 \mathrm{M}$. ovinus parasites in a Petri dish containing $3-5 \mathrm{~mL}$ of the extracts for 1 minute. Two percent Tween 80 and water were used as negative control and $10 \mu \mathrm{g} / \mathrm{mL}$ Ivermectin was used as positive control. The experiment was performed in triplicate and the Petri dishes were incubated at $27-28^{\circ} \mathrm{C}$ and $80 \%$ relative humidity for $24 \mathrm{~h}$. The parasites were studied with stereomicroscope and the mortality was recorded at $3 \mathrm{~h}$ interval till $24 \mathrm{~h}$ by counting dead parasites (alive and dead) and the corrected mortality rate of $3 \mathrm{~h}$ and $24 \mathrm{~h}$ was reported. The percent mortality rate of the tick was calculated as per Abotts (1925) as cited in [30]:

$$
\begin{aligned}
& \text { Corrected Mortality } \\
& \qquad=\frac{\% \text { Treated mortality }-\% \text { control mortality }}{100-\% \text { control mortality }} \times 100 \text {. }
\end{aligned}
$$

2.4. Data Analysis. Insecticidal effect was classified as follows: strong, mortality $>80 \%$; moderate, mortality $80-60 \%$; weak, mortality $60-40 \%$; little or no activity, mortality $<40 \%$. Mortality in the Petri dishes treated with extract was corrected to take account of control mortality using Abbott's correction. The mortality rates were determined and transformed and subjected to analysis of variance (ANOVA) using statistical software (Minitab 16.0, England). Post hoc testing was done using Tukey. Percent mortality and values were presented as mean \pm S.D. Insecticidal activity was considered to be significantly different when $95 \%$ confidence limit levels failed to overlap or if $P$ value $<0.05$.

\section{Results}

A total of 12 extracts from 12 different medicinal plants were tested for insecticidal activity against $M$. ovinus. The insecticidal activity of essential oils of C. citratus, E. globulus, and $F$. vulgare at a concentration of $0.7825,1.565,3.13,6.25$, $12.5,25$, and $50 \mu \mathrm{L} / \mathrm{mL}$ against adult $M$. ovinus sheep ked is shown in Table 1. The result showed that C. citratus essential oil has pronounced insecticidal activity followed by F. vulgare and E. globulus. Hundred percent mortalities were recorded by C. citratus, F. vulgare, and E. globulus against $M$. ovinus within $3 \mathrm{~h}$ of exposure at a concentration of $3.13 \mu \mathrm{L} / \mathrm{mL}, 6.25 \mu \mathrm{L} / \mathrm{mL}$, and $12.5 \mu \mathrm{L} / \mathrm{mL}$, respectively. Sheep ked mortality increased as concentration and exposure time to the essential oil increased.

Statistical results (one-way ANOVA (unstacked)) have showed significantly higher insecticidal activity of essential oils $(P<0.01)$ after a $3 \mathrm{~h}$ exposure of $M$. ovinus to concentrations of $\geq 1.57 \mu \mathrm{L} / \mathrm{mL}, \geq 3 \mu \mathrm{L} / \mathrm{mL}$, and $\geq 12.7 \mu \mathrm{L} / \mathrm{mL}$ essential oils of C. citratus, F. vulgare, and E. globulus, respectively, as compared with $10 \mu \mathrm{g} / \mathrm{mL}$ Ivermectin. Among the essential oils, at $3 \mathrm{~h}$ exposure of the parasite, significantly higher $(P<0.01)$ insecticidal activity was exerted by $C$. citratus at a concentration $\geq 0.78 \mu \mathrm{L} / \mathrm{mL}$.

Mortality of M. ovinus sheep keds exposed to aqueous extract of C. aurea, X. caffras and J. curcas at concentration of $6.25,12.5,25,50,100$, and $200 \mathrm{mg} / \mathrm{mL}$ is shown in Table 2 . The maximum antiparasitic activity was exerted by aqueous extract of $C$. aurea. Eighty percent, $60 \%$ and $66.3 \%$ mortality of $M$. ovinus sheep keds were observed after $24 \mathrm{~h}$ of exposure to $200 \mathrm{mg} / \mathrm{mL}$ of C. aurea, X. caffra, and J. curcas, respectively. The highest insecticidal efficacy was recorded by $C$. aurea with (73.3\%) mortality followed by X. caffra (60\%) and $J$. curcas $(56.7 \%)$ at a concentration of $200 \mathrm{mg} / \mathrm{mL}$, within 3 hours of the parasite exposure. 
TABLE 2: The corrected mortalities of M. ovinus sheep keds exposed to different concentrations of aqueous extracts of $C$. aurea leaves, $X$. caffra fruits, and J. curcas fruits.

\begin{tabular}{|c|c|c|c|c|c|c|}
\hline \multirow{3}{*}{ Dose $(\mathrm{mg} / \mathrm{mL})$} & \multicolumn{6}{|c|}{ Corrected mortality rate (\%) } \\
\hline & \multicolumn{2}{|c|}{ C. aurea } & \multicolumn{2}{|c|}{ X. caffra } & \multicolumn{2}{|c|}{ J. curcas } \\
\hline & $3 \mathrm{~h}$ PI & $24 \mathrm{~h}$ PI & $3 \mathrm{~h}$ PI & $24 \mathrm{~h}$ PI & $3 \mathrm{~h}$ PI & $24 \mathrm{~h}$ PI \\
\hline 6.24 & $0.0 \pm 0.0^{\mathrm{d}}$ & $0.0 \pm 0.0^{\mathrm{a}}$ & $0.0 \pm 0.0^{\mathrm{d}}$ & $0.0 \pm 0.0^{\mathrm{d}}$ & $0.0 \pm 0.0^{\mathrm{c}}$ & $0.0 \pm 0.0^{\mathrm{e}}$ \\
\hline 12.5 & $13.3 \pm 0.6^{\mathrm{cd}}$ & $16.7 \pm 0.6^{\mathrm{d}}$ & $10.0 \pm 0.0^{\mathrm{cd}}$ & $10.0 \pm 0.0^{\mathrm{d}}$ & $0.0 \pm 0.0^{c}$ & $6.7 \pm 0.6^{\mathrm{e}}$ \\
\hline 25 & $13.3 \pm 0.6^{\mathrm{cd}}$ & $23.3 \pm 0.6^{\mathrm{d}}$ & $20.0 \pm 1.0^{\mathrm{bc}}$ & $23.3 \pm 0.6^{\mathrm{c}}$ & $6.7 \pm 0.6^{\mathrm{bc}}$ & $13.3 \pm 0.6^{\mathrm{de}}$ \\
\hline 50 & $26.7 \pm 0.6^{c}$ & $27.8 \pm 1.0^{\mathrm{d}}$ & $26.7 \pm 0.6^{\mathrm{b}}$ & $30.0 \pm 0.0^{c}$ & $16.7 \pm 1.0^{\mathrm{bc}}$ & $23.3 \pm 0.6^{\mathrm{cd}}$ \\
\hline 100 & $53.3 \pm 0.6^{\mathrm{b}}$ & $63.3 \pm 0.6^{c}$ & $33.3 \pm 0.6^{\mathrm{b}}$ & $50.0 \pm 1.0^{\mathrm{b}}$ & $23.3 \pm 1.0^{\mathrm{b}}$ & $33.3 \pm 0.6^{\mathrm{c}}$ \\
\hline 200 & $73.3 \pm 0.6^{\mathrm{a}}$ & $80.0 \pm 0.0^{\mathrm{b}}$ & $60.0 \pm 0.0^{\mathrm{a}}$ & $60.0 \pm 0.0^{\mathrm{b}}$ & $56.7 \pm 0.6^{\mathrm{a}}$ & $66.3 \pm 0.6^{\mathrm{b}}$ \\
\hline Control $^{+}$ & $73.3 \pm 0.6^{\mathrm{a}}$ & $100.0 \pm 0.0^{\mathrm{a}}$ & $73.3 \pm 0.6^{\mathrm{a}}$ & $100.0 \pm 0.0^{\mathrm{a}}$ & $73.3 \pm 0.6^{\mathrm{a}}$ & $100.0 \pm 0.0^{\mathrm{a}}$ \\
\hline
\end{tabular}

${ }^{+}$Ivermectin $(10 \mu \mathrm{g} / \mathrm{mL})$; PI: postincubation; values are expressed as mean \pm SD. Mean values with different letters in the same column are significantly different $(P<0.05)$.

TAble 3: Percent corrected mortality of M. ovinus sheep keds exposed to different concentrations of S. guineense, N. tabacum, and V. auriculifera aqueous extracts.

\begin{tabular}{|c|c|c|c|c|c|c|}
\hline \multirow{3}{*}{ Dose $(\mathrm{mg} / \mathrm{mL})$} & \multicolumn{6}{|c|}{ Corrected mortality rate (\%) } \\
\hline & \multicolumn{2}{|c|}{ S. guineense } & \multicolumn{2}{|c|}{ N. tabacum } & \multicolumn{2}{|c|}{ V. auriculifera } \\
\hline & $3 \mathrm{~h}$ PI & 24 h PI & $3 \mathrm{~h}$ PI & $24 \mathrm{~h}$ PI & $3 \mathrm{~h}$ PI & $24 \mathrm{~h}$ PI \\
\hline 6.24 & $0.0 \pm 0.0^{\mathrm{e}}$ & $0.0 \pm 0.0^{\mathrm{d}}$ & $0.0 \pm 0.0^{c}$ & $0.0 \pm 0.0^{\mathrm{e}}$ & $0.0 \pm 0.0^{c}$ & $0.0 \pm 0.0^{\mathrm{e}}$ \\
\hline 12.5 & $3.3 \pm 0.6^{\mathrm{de}}$ & $6.7 \pm 0.6^{\mathrm{d}}$ & $0.0 \pm 0.0^{c}$ & $6.6 \pm 0.6^{\mathrm{de}}$ & $6.7 \pm 0.6^{\mathrm{bc}}$ & $6.7 \pm 0.6^{\mathrm{de}}$ \\
\hline 25 & $13.3 \pm 0.6^{\mathrm{cd}}$ & $13.9 \pm 0.6^{\mathrm{cd}}$ & $6.6 \pm 0.6^{c}$ & $16.7 \pm 0.6^{\mathrm{cd}}$ & $10.0 \pm 0.0^{\mathrm{bc}}$ & $13.3 \pm 0.6^{\text {cde }}$ \\
\hline 50 & $20.0 \pm 0.0^{c}$ & $23.3 \pm 0.6^{c}$ & $10.0 \pm 0.0^{c}$ & $20.0 \pm 0.0^{c}$ & $10.0 \pm 0.0^{b c}$ & $16.7 \pm 0.6^{\mathrm{cd}}$ \\
\hline 100 & $40.0 \pm 0.0^{\mathrm{b}}$ & $43.3 \pm 0.6^{\mathrm{b}}$ & $13.3 \pm 0.6^{c}$ & $36.7 \pm 0.6^{\mathrm{b}}$ & $16.7 \pm 0.6^{\mathrm{b}}$ & $23.3 \pm 0.6^{c}$ \\
\hline 200 & $43.5 \pm 0.6^{\mathrm{b}}$ & $46.7 \pm 0.6^{\mathrm{b}}$ & $20.0 \pm 0.0^{\mathrm{b}}$ & $43.3 \pm 0.6^{\mathrm{b}}$ & $20.0 \pm 0.0^{\mathrm{b}}$ & $43.3 \pm 0.6^{\mathrm{b}}$ \\
\hline Control $^{+}$ & $73.3 \pm 0.6^{\mathrm{a}}$ & $100.0 \pm 0.0^{\mathrm{a}}$ & $73.3 \pm 0.6^{\mathrm{a}}$ & $100.0 \pm 0.0^{\mathrm{a}}$ & $73.3 \pm 0.6^{\mathrm{a}}$ & $100.0 \pm 0.0^{\mathrm{a}}$ \\
\hline
\end{tabular}

${ }^{+}$Ivermectin $(10 \mu \mathrm{g} / \mathrm{mL})$; PI: postincubation; values are expressed as mean \pm SD. Mean values with different letters in the same column are significantly different $(P<0.05)$.

Table 3 indicated the antiparasitic activity of different concentrations of aqueous extracts of S. guineense, $N$. tabacum, and V. auriculifera against M. ovinus sheep keds. A $43.5 \%$ mortality of sheep keds was recorded by S. guineense at a concentration of $200 \mathrm{mg} / \mathrm{mL}$ within $3 \mathrm{~h}$ of exposure, while a comparatively lower mortality rate $(20 \%)$ was recorded by both $N$. tabacum and $V$. auriculifera within $3 \mathrm{~h}$ of exposure. All extracts exerted significantly lower insecticidal effect when compared to $10 \mu \mathrm{g} / \mathrm{mL}$ Ivermectin $(P<0.05)$.

The effects of Aloe sp., B. abyssinica, and C. macrostachyus on $M$. ovinus sheep ked are also shown in Table 4 . The exposure of M. ovinus sheep ked to the dose of $200 \mathrm{mg} / \mathrm{mL}$ of Aloe sp., were showed mortality of $30 \%$ within $3 \mathrm{~h}$. Relatively, a higher antiparasitic potential was recorded by Aloe sp. than the other species.

\section{Discussion}

Though Ethiopia has a potential of supplying livestock and livestock products, the sector is facing multiple challenges and ectoparasites continued to be highly prevalent; even the most commonly used insecticides are becoming ineffective due to the development of resistance in addition, environment pollution and health risk of the insecticide [7]. These problems had stimulated a great deal of research to look for alternative treatment from natural products. For this purpose we evaluated activity of twelve traditionally used Ethiopian medicinal plants for the alternative management of sheep ked infestation. Application of plants essential oils or plant extracts for the control of pest has been used for hundreds of years by the community and practitioners of traditional medicine. Similarly, various studies showed the antiparasitic and insecticidal properties of the plant essential oils against phytophagous pests, ticks [31], and mites $[22,23]$.

Our findings have confirmed that essential oils from C. citratus, E. globulus, and F. vulgare have antiparasitic activity against $M$. ovinus. Essential oil of $C$. citratus has pronounced insecticidal activity followed by $F$. vulgare and E. globulus. Complete immobility of the sheep ked parasite was recorded at a concentration of $3.13 \mu \mathrm{L} / \mathrm{mL}, 6.25 \mu \mathrm{L} / \mathrm{mL}$, and $12.5 \mu \mathrm{L} / \mathrm{mL}$ essential oils of $C$. citrates, F. vulgare, and $E$. globules, respectively. The insecticidal effect of the essential oils are depends on both dose and type of plant species as the significant effect was recorded at higher dose level. Moreover, the highest mortality effect against $M$. ovinus was observed by $C$. citratus which is considered as the best insecticidal agent among the investigated plants. Our finding that essential oils have insecticidal activity is in line with several studies where they indicated that many essential 
TABLE 4: The corrected mortality rate of $M$. ovinus sheep keds exposed to different concentrations of Aloe species, B. abyssinica, and C. macrostachyus leaves aqueous extracts.

\begin{tabular}{|c|c|c|c|c|c|c|}
\hline \multirow{3}{*}{ Dose $(\mathrm{mg} / \mathrm{mL})$} & \multicolumn{6}{|c|}{ Corrected mortality rate (\%) } \\
\hline & \multicolumn{2}{|c|}{ Aloe sp. } & \multicolumn{2}{|c|}{ C. macrostachyus } & \multicolumn{2}{|c|}{ B. abyssinica } \\
\hline & $3 \mathrm{~h}$ PI & 24 h PI & $3 \mathrm{~h}$ PI & $24 \mathrm{~h}$ PI & $3 \mathrm{~h}$ PI & $24 \mathrm{~h}$ PI \\
\hline 6.24 & $0.0 \pm 0.0^{\mathrm{d}}$ & $0.0 \pm 0.0^{c}$ & $0.0 \pm 0.0^{\mathrm{d}}$ & $0.0 \pm 0.0^{\mathrm{d}}$ & $0.0 \pm 0.0^{\mathrm{d}}$ & $0.0 \pm 0.0^{\mathrm{d}}$ \\
\hline 12.5 & $6.7 \pm 0.6^{\mathrm{cd}}$ & $6.7 \pm 0.6^{c}$ & $6.7 \pm 0.6^{\mathrm{d}}$ & $6.7 \pm 0.6^{\mathrm{d}}$ & $0.0 \pm 0.0^{\mathrm{d}}$ & $0.0 \pm 0.0^{\mathrm{d}}$ \\
\hline 25 & $13.3 \pm 0.6^{c}$ & $13.3 \pm 0.6^{c}$ & $6.7 \pm 0.6^{\mathrm{d}}$ & $6.7 \pm 0.6^{\mathrm{cd}}$ & $0.0 \pm 0.0^{\mathrm{d}}$ & $6.7 \pm 0.6^{\mathrm{cd}}$ \\
\hline 50 & $13.3 \pm 0.6^{\mathrm{c}}$ & $13.3 \pm 0.6^{c}$ & $6.7 \pm 0.6^{\mathrm{cd}}$ & $6.7 \pm 0.6^{\mathrm{bc}}$ & $6.7 \pm 0.6^{\mathrm{cd}}$ & $16.7 \pm 0.6^{\mathrm{bc}}$ \\
\hline 100 & $30.0 \pm 0.0^{\mathrm{b}}$ & $40.0 \pm 1.0^{\mathrm{b}}$ & $26.7 \pm 0.6^{\mathrm{bc}}$ & $26.7 \pm 0.6^{\mathrm{b}}$ & $16.7 \pm 0.6^{\mathrm{bc}}$ & $20.0 \pm 0.0^{\mathrm{b}}$ \\
\hline 200 & $30.0 \pm 0.0^{\mathrm{b}}$ & $40.0 \pm 1.0^{\mathrm{b}}$ & $30.0 \pm 0.0^{\mathrm{b}}$ & $30.0 \pm 0.0^{\mathrm{b}}$ & $23.3 \pm 0.6^{\mathrm{b}}$ & $26.7 \pm 0.6^{\mathrm{b}}$ \\
\hline Control $^{+}$ & $73.3 \pm 0.6^{\mathrm{a}}$ & $100.0 \pm 0.0^{\mathrm{a}}$ & $73.3 \pm 0.6^{\mathrm{a}}$ & $100.0 \pm 0.0^{\mathrm{a}}$ & $73.3 \pm 0.6^{\mathrm{a}}$ & $100.0 \pm 0.0^{\mathrm{a}}$ \\
\hline
\end{tabular}

${ }^{+}$Ivermectin $(10 \mu \mathrm{g} / \mathrm{mL})$; PI: postincubation; values are expressed as mean \pm SD. Mean values with different letters in the same column are significantly different $(P<0.05)$.

oils could possibly substitute synthetic chemicals [32], with higher insecticidal effect of C. citratus against mite [26], insecticidal potentials of $F$. vulgare fruit against mite and a significant dose dependent insecticidal effect of E. globulus against tick [33]. The mortality of the parasite may be due to the octopaminergic nervous system interference by these essential oils [34]. Similarly, the activity could be due to complex mixture of secondary metabolites like terpenoids, phenolics of mono-, di- and sesquiterpenes, specifically citral, elemicin, (+)-fenchone, and p-anisaldehyde, and 1,8-cineole in the essential oils [34]. The difference in bioactivity between the essential oils may be due to the difference in major compounds, as biological activity of essential oils depends on chemical structure of their components [35, 36]. Moreover, chemical components may be toxic to various pests individually or in combination. Activity may be also influenced by the arrangement of multiple components in the essential oils as a result of synergistic effects [23].

Another notable finding of the current study was that aqueous extract of plants has insecticidal activity. Promising activity ( $80 \%$ mortality) was recorded by C. aurea, while $60 \%$ mortality by $X$. caffra, and about $57 \%$ mortality by J. curcas are still worth a credit as potential source of botanical insecticide. Our study that confirmed C. aurea has remarkable antiparasitic activity replicates a previous study [24], which reported $85 \%$ mortality of tick at $5 \%$ concentration of C. aurea. Moreover, aqueous extracts of $J$. curcas and $X$. caffra have a potential of killing or immobilizing $M$. ovinus sheep keds which is in line with previous study [27].

Moreover, the finding of current study showed that aqueous extracts of S. guineense, $N$. tabacum, and V. auriculifera have moderate toxicity against $M$. ovinus sheep keds. A mortality of $47 \%$ was recorded within $24 \mathrm{~h}$ of exposure of sheep ked parasite to $200 \mathrm{mg} / \mathrm{mL}$ of $S$. guineense. The antiparasitic effect observed by $S$. guineense was also supported by the findings of closely related species [25] on the ethanolic extract of Syzygium cumini that showed the highest antiparasitic (98.5\% mortality) effect. Our findings also replicate the finding of Zaman et al. [28] whereby mortality of tick parasite was reported to be in combination with application of
Azadirachta indica and N. tabacum leaves, Calotropis procera flowers, and Trachyspermum ammi seeds aqueous extracts.

Many of the plants used in this study which showed insecticidal activity are reported to have ethnoveterinary medicine practices in Ethiopia as elsewhere in the world [37]. However, our finding showed that aqueous extracts of Aloe sp., B. abyssinica, and C. macrostachyus have lower lethality activity against $M$. ovinus when compared to other plants and that of the commercially used antiparasite Ivermectin. This could be due to the extraction method we used; one can find higher activity by using other extractants than water. Similarly, various studies reported the antihelminthic activity of Aloe sp. [38] and the antimicrobial activity of B. abyssinica [39] and C. macrostachyus [40]. This could be an indication of the broad spectrum activity of the plant extracts.

\section{Conclusion}

The current study showed that the essential oils of C. citratus, E. globulus, and F. vulgare and the aqueous extract of $C$. aurea have strong insecticidal activity. The results of this study offer some scientific credence to the traditional uses of the Ethiopian medicinal plants evaluated for the management of Sheep ked parasites. There are many opportunities for the use of plant essential oils as alterative to synthetic insecticide; one is their insecticidal potency and environmental sound nature, easy accessibility by the rural pastoralist community, and superiority over synthetic antiparasite Ivermectin. Another important opportunity is their easy application as fumigant and topical treatment. Regarding C. aurea, it can be one potential alternative to synthetic insecticide to control sheep ked which is advantageous by its wide occurrence in Ethiopia and its capacity to resist drought and overgrazing. There is, however, a need for further investigation on their safety and efficacy (in vivo and under natural conditions) as well as costeffectiveness of the products that exhibited strong insecticidal activity with a view of substituting the conventional organophosphorus drugs. And also we recommend bioassay guided fractionation, isolation, and characterization of the responsible active components of the plant materials. 


\section{Conflict of Interests}

The authors declare that there is no conflict of interests regarding the publication of this paper.

\section{Acknowledgments}

Financial support for this study was provided through EHN RI by the Ministry of Finance and Economic Development (through Project no. 342/02/04/01/007). The authors would like to thank the National Animal Health Diagnostic and Investigation Center for their technical assistance during the initiation phase of the project. They also acknowledge the Wondo Genet Agricultural Research Center, Ethiopian Institute of Agricultural Research (WGARC-EIAR) for providing them with essential oils of two medicinal plants. They are also grateful to the Grar-Jarso District, North Shewa Oromia Zone Agricultural Office, for their support in identification and giving them permission to undertake the project.

\section{References}

[1] A. Solomon, A. Workalemahu, M. A. Jabbar, M. M. Ahmed, and B. Hurissa, "Livestock marketing in Ethiopia: a review of structure, performance and development initiatives," SocioEconomic and Policy Research Working Paper 52, IILR Institute, Nairobi, Kenya, 2003.

[2] FAO. Ethiopia, “TCP/ETH/2908 TCP/ETH/2908 (I) (NEPAD Ref. 05/08 E)," NEPAD-Comprehensive Africa Agriculture Development Programme. Ethiopia: Investment Project Profile "Live Animal and Meat Export"-Preliminary Options Outline, 2005.

[3] Y. Abadi, "Current problems of the leather industry," in The Opportunities and Challenges of Enhancing Goat Production in East Africa, R. C. Merkel, G. Abebe, and A. L. Goetsch, Eds., Proceedings of a Conference Held at Debub University, Awassa, Ethiopia from November 10 to 12, 2000, pp. 139-143, E (Kika) de la Garza Institute for Goat Research, Langston University, Langston, Okla, USA, 2000.

[4] W. Berhanu, H. Negussie, S. Alemu, and H. Mazengia, "Assessment on major factors that cause skin rejection at Modjo export tannery, Ethiopia," Tropical Animal Health and Production, vol. 43, no. 5, pp. 989-993, 2011.

[5] S. Zewdie, Control of External Parasites in Sheep and Goats, Ethiopia Sheep and Goat Productivity Improvement Program (ESGPIP), 2010.

[6] K. Bayou, "Control of sheep and goatskin diseases," in Proceedings of the Control of Sheep and Goat Skin Diseases for Improved Quality of Hides and Skin, B. C. Ian and B. Bayou, Eds., FAO, Addis Ababa, Ethiopia, February 1998.

[7] R. Wall, "Ectoparasites: future challenges in a changing world," Veterinary Parasitology, vol. 148, no. 1, pp. 62-74, 2007.

[8] M. Chanie, T. Negash, and A. Sirak, "Ectoparasites are the major causes of various types of skin lesions in small ruminants in Ethiopia," Tropical Animal Health and Production, vol. 42, no. 6, pp. 1103-1109, 2010.

[9] B. Kumsa, K. Beyecha, and M. Geloye, "Ectoparasites of sheep in three agro-ecological zones in central Oromia, Ethiopia," Onderstepoort Journal of Veterinary Research, vol. 79, pp. E1-E7, 2012.
[10] R. W. Small, "A review of Melophagus ovinus (L.), the sheep ked," Veterinary Parasitology, vol. 130, no. 1-2, pp. 141-155, 2005.

[11] R. W. Sutherst and L. J. Wilson, "Tropical legumes and their ability to immobilize and kill cattle ticks," in Insect and the Plant Surface, B. E. Juniper and T. R. E. Southwood, Eds., pp. 185-194, Edward Arnold, London, UK, 1986.

[12] P. Kaufman and D. Rutz, Pest Management Recommendations for Sheep, Goats, and Swine, A Cornell and Penn State Cooperative Extension Publication, 2010.

[13] J. W. Plant and C. J. Lewis, "Treatment and control of ectoparasites in sheep," Veterinary Clinics of North America-Food Animal Practice, vol. 27, no. 1, pp. 203-212, 2011.

[14] A. Lifschitz, S. Nava, A. A. Guglielmone et al., "Failure of ivermectin and eprinomectin to control Amblyomma parvum in goats: characterization of acaricidal activity and drug pharmacokinetic disposition," Veterinary Parasitology, vol. 156, no. 3-4, pp. 284-292, 2008.

[15] S. Kumar, S. Paul, A. K. Sharma et al., "Diazinon resistant status in Rhipicephalus (Boophilus) microplus collected from different agro-climatic regions of India," Veterinary Parasitology, vol. 181, no. 2-4, pp. 274-281, 2011.

[16] G. C. Brander and D. M. Pugh, Veterinary Applied Pharmacology \& Therapeutics, The English Language Book Society \& Bailliere Tindall, London, UK, 1977.

[17] T. Namba, "Cholinesterase inhibition by organophosphorus compounds and its clinical effects," Bulletin of the World Health Organization, vol. 44, no. 1, pp. 289-307, 1971.

[18] V. V. Zharov, S. Teferra, M. Mekuria, and B. Woldekidan, "The status of health of Ethiopian agricultural workers involved in the use of pesticides," Ethiopian Medical Journal, vol. 19, article $165,1981$.

[19] V. V. Zharov, S. Teferra, and M. Mekuria, "Toxicological assessment of action of pestcides on the health of agricultural workers," Ethiopian Medical Journal, vol. 20, article 160, 1982.

[20] J. Grønvold, S. A. Henriksen, M. Larsen, P. Nansen, and J. Wolstrup, "Biological control. Aspects of biological control: with special reference to arthropods, protozoans and helminths of domesticated animals," Veterinary Parasitology, vol. 64, no. 1-2, pp. 47-64, 1996.

[21] A. D. Kinghorn and D. D. Soejarto, "Discovery of terpenoid and phenolic sweeteners from plants," Pure and Applied Chemistry, vol. 74, no. 7, pp. 1169-1179, 2002.

[22] H. Lee, "Acaricidal activity of constituents identified in Foeniculum vulgare fruit oil against Dermatophagoides spp. (Acari: Pyroglyphidae)," Journal of Agricultural and Food Chemistry, vol. 52, no. 10, pp. 2887-2889, 2004.

[23] D. R. George, D. Masic, O. A. E. Sparagano, and J. H. Guy, "Variation in chemical composition and acaricidal activity against Dermanyssus gallinae of four eucalyptus essential oils," Experimental and Applied Acarology, vol. 48, no. 1-2, pp. 43-50, 2009.

[24] A. Zorloni, B. L. Penzhorn, and J. N. Eloff, "Extracts of Calpurnia aurea leaves from southern Ethiopia attract and immobilise or kill ticks," Veterinary Parasitology, vol. 168, no. 1-2, pp. 160-164, 2010.

[25] A. E. M. Afify, H. S. El-Beltagi, S. A. Fayed, and E. A. Shalaby, "Acaricidal activity of different extracts from Syzygium cumini L. Skeels (Pomposia) against Tetranychus urticae Koch," Asian Pacific Journal of Tropical Biomedicine, vol. 1, no. 5, pp. 359-364, 2011. 
[26] A. L. Hanifah, S. H. Awang, H. T. Ming, S. Z. Abidin, and M. H. Omar, "Acaricidal activity of Cymbopogon citratus and Azadirachta indica against house dust mites," Asian Pacific Journal of Tropical Biomedicine, vol. 1, no. 5, pp. 365-369, 2011.

[27] S. Juliet, R. Ravindran, S. A. Ramankutty et al., "Jatropha curcas (Linn) leaf extract-a possible alternative for population control of Rhipicephalus (Boophilus) annulatus," Asian Pacific Journal of Tropical Disease, no. 3, pp. 225-229, 2012.

[28] M. A. Zaman, Z. Iqbal, R. Z. Abbas et al., "In vitro and in vivo acaricidal activity of a herbal extract," Veterinary Parasitology, vol. 186, no. 3-4, pp. 431-436, 2012.

[29] J. A. Rosado-Aguilar, A. Aguilar-Caballero, R. I. RodriguezVivas, R. Borges-Argaez, Z. Garcia-Vazquez, and M. MendezGonzalez, "Acaricidal activity of extracts from Petiveria alliacea (Phytolaccaceae) against the cattle tick, Rhipicephalus (Boophilus) microplus (Acari: ixodidae)," Veterinary Parasitology, vol. 168, no. 3-4, pp. 299-303, 2010.

[30] E. T. Pamo, F. Tendonkeng, J. R. Kana et al., "A study of the acaricidal properties of an essential oil extracted from the leaves of Ageratum houstonianum," Veterinary Parasitology, vol. 128, no. 3-4, pp. 319-323, 2005.

[31] A. Iori, D. Grazioli, E. Gentile, G. Marano, and G. Salvatore, "Acaricidal properties of the essential oil of Melaleuca alternifolia Cheel (tea tree oil) against nymphs of Ixodes ricinus," Veterinary Parasitology, vol. 129, no. 1-2, pp. 173-176, 2005.

[32] M. B. Isman, "Plant essential oils for pest and disease management," Crop Protection, vol. 19, no. 8-10, pp. 603-608, 2000.

[33] K. Pirali-Kheirabadi, M. Razzaghi-Abyaneh, and A. Halajian, "Acaricidal effect of Pelargonium roseum and Eucalyptus globulus essential oils against adult stage of Rhipicephalus (Boophilus) annulatus in vitro," Veterinary Parasitology, vol. 162, no. 3-4, pp. 346-349, 2009.

[34] O. Koul, S. Walia, and G. S. Dhaliwal, "Essential oils as green pesticides: potential and constraints," Biopesticides International, vol. 4, no. 1, pp. 63-84, 2008.

[35] E. Guenther, The Essential Oils, 1961.

[36] S. E. Megalla, N. E. M. El-Keltawi, and S. A. Ross, "A study of antimicrobial action of some essential oil constituents," Herba Polonica, vol. 3, pp. 181-1186, 1980.

[37] F. Fullas, "Ethiopian medicinal plants in veterinary heath care: a mini-review," Ethiopian e-Journal for Research and Innovation Foresight, vol. 2, no. 1, pp. 48-58, 2010.

[38] M. M. Gakuubi and W. Wanzala, "A survey of plants and plant products traditionally used in livestock health management in Buuri district, Meru County, Kenya," Journal of Ethnobiology and Ethnomedicine, vol. 8, no. 1, article 39, 2012.

[39] G. E. K. Bolou, I. Bagré, K. Ouattara, and A. J. Djaman, "Evaluation of the antibacterial activity of 14 medicinal plants in Côte d'Ivoire," Tropical Journal of Pharmaceutical Research, vol. 10, no. 3, pp. 335-340, 2011.

[40] B. Taye, M. Giday, A. Animut, and J. Seid, "Antibacterial activities of selected medicinal plants in traditional treatment of human wounds in Ethiopia," Asian Pacific Journal of Tropical Biomedicine, vol. 1, no. 5, pp. 370-375, 2011. 

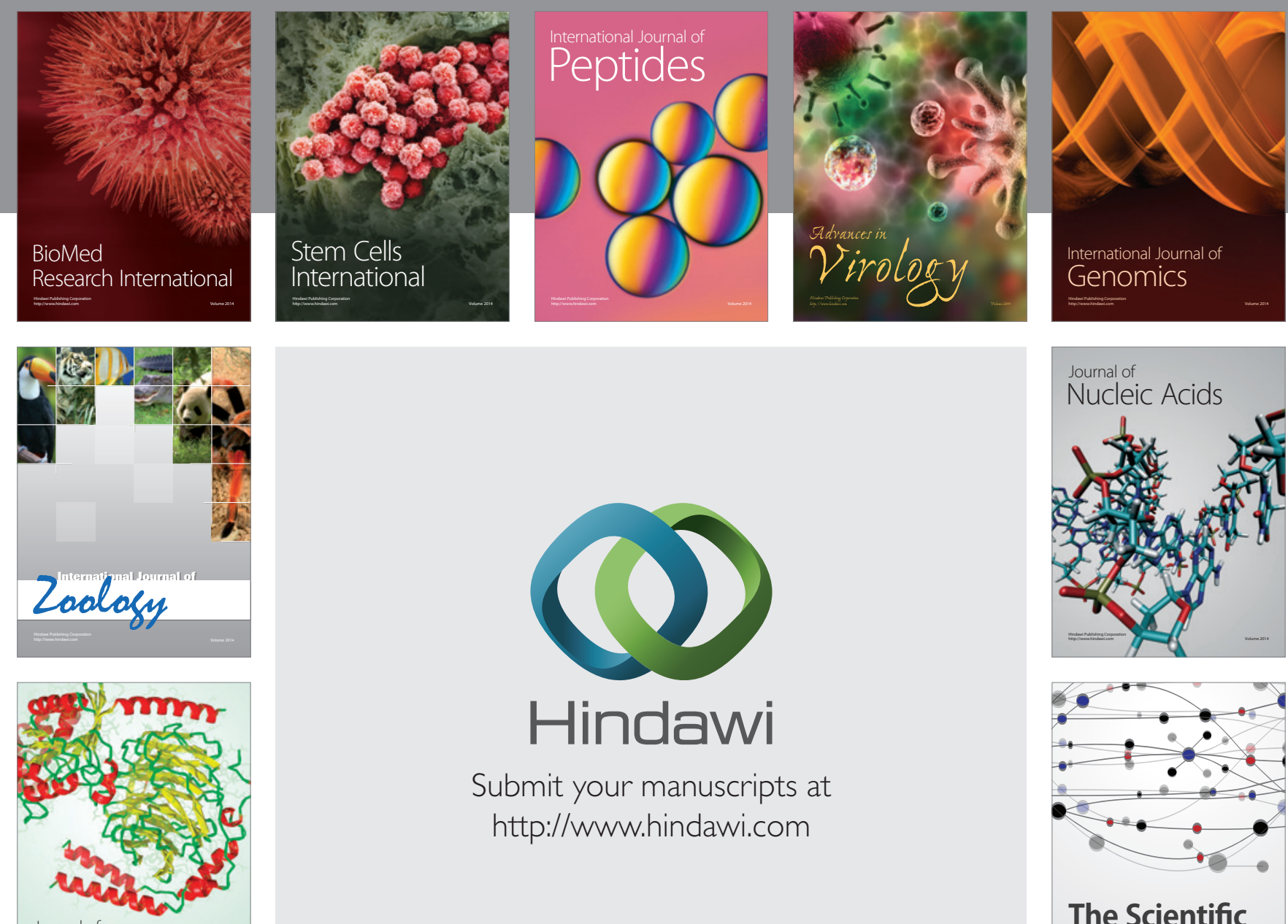

Submit your manuscripts at

http://www.hindawi.com

Journal of
Signal Transduction
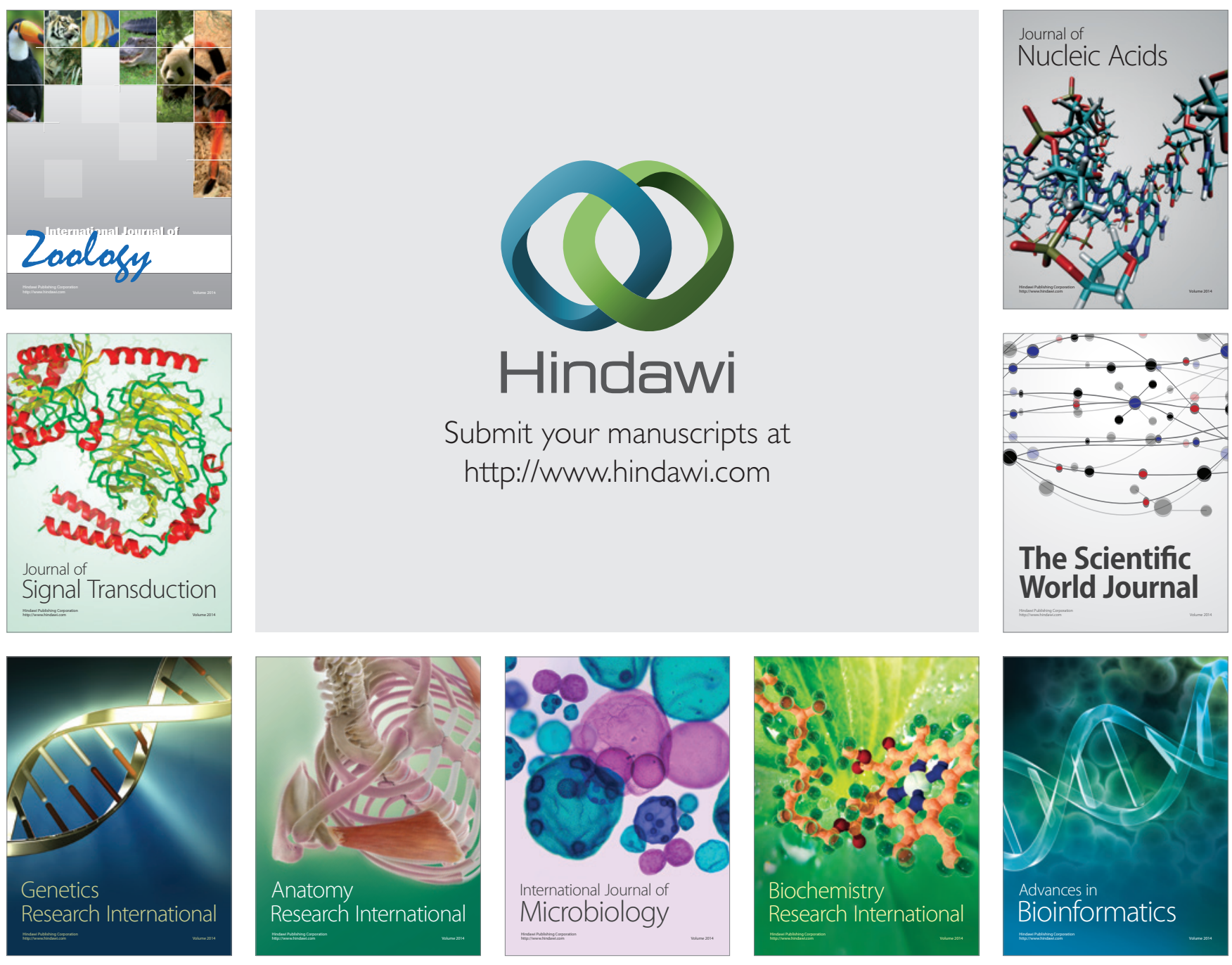

The Scientific World Journal
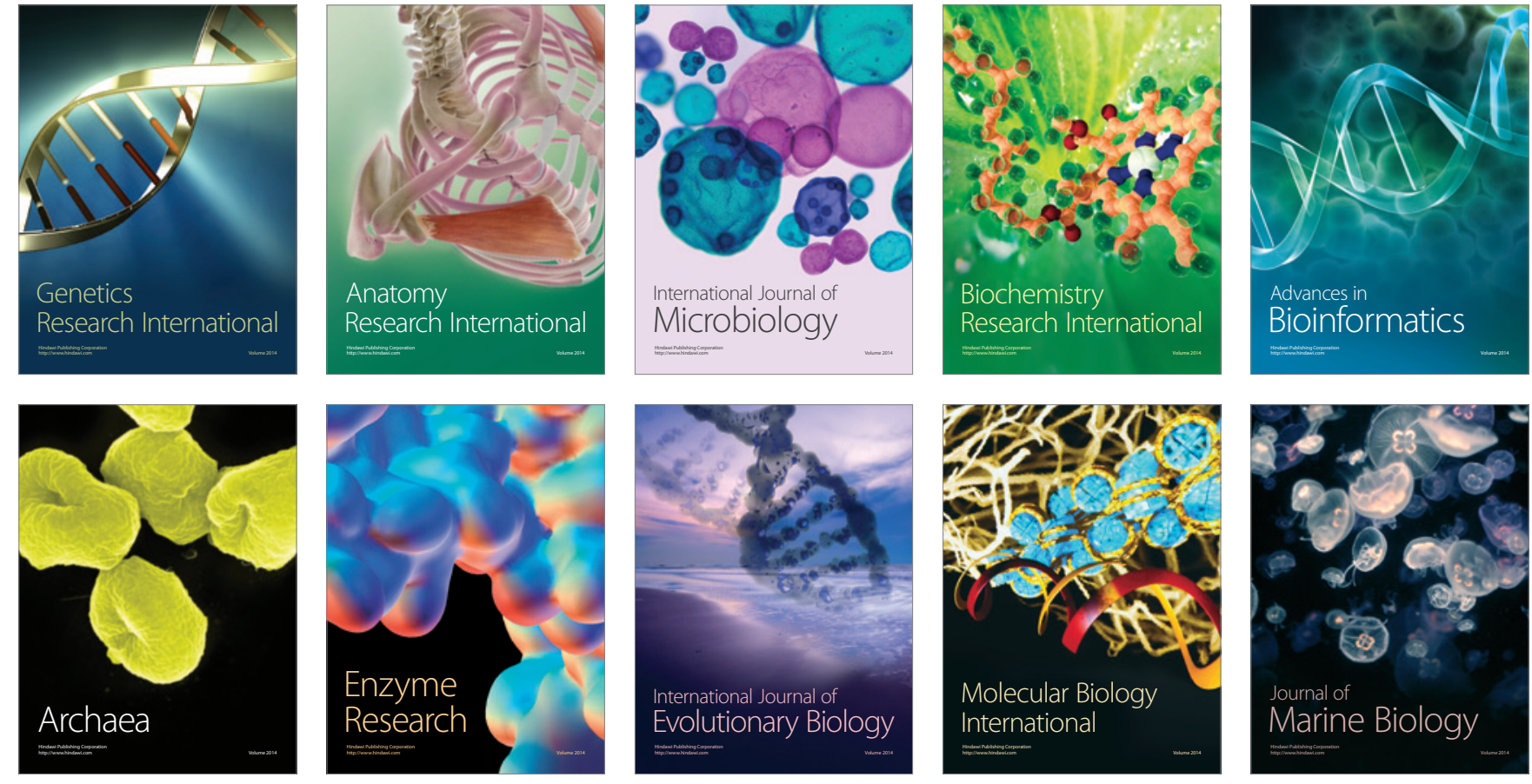